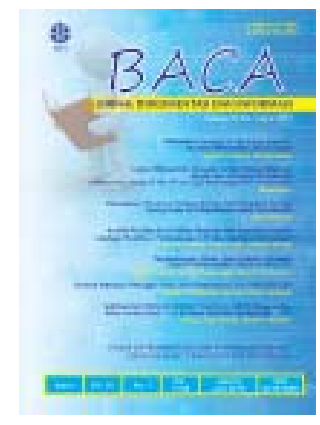

\title{
ZOO INDONESIA: SUATU STUDI INFORMETRIKA
}

\author{
Muthia Nurhayati $^{1^{*}}$ \\ ${ }^{1}$ Pusat Penelitian Biologi LIPI \\ ${ }^{1}$ Program Pasca Sarjana Ilmu Perpustakaan Fakultas Ilmu Budaya Universitas Indonesia \\ *Korespondensi:muthia.nurhayati@gmail.com
}

Diajukan: 9-1-2015; Direview: 27-1-2016; Diterima: 11-3-2016; Direvisi: 2-5-2016

\begin{abstract}
This study aims to determine the development of Tropical Fauna Journal Zoo Indonesia which includes article distribution, patterns of authorship and fauna research subject at issue in 1983-2014. This study uses informetrics analysis of all articles in the journal. The results showed: (1) the distribution of articles on every volume published by Zoo Indonesia have increased with the last number is six articles on each volume to its publication; (2) authorship patterns show the dominant by single author of 46,08\%; and (3) research subjects that most discussed is about arthropods amounted to 30,41\%. The conclusion is Zoo Indonesia on his way continuously tries to improve its quality as a scientific journal by a system of e-journal and also continue to fix both physically and editorial system aspects in it.
\end{abstract}

\begin{abstract}
ABSTRAK
Penelitian ini bertujuan untuk mengetahui perkembangan Jurnal Fauna Tropika Zoo Indonesia, yang meliputi distribusi artikel, pola kepengarangan, dan subjek penelitian fauna pada terbitan tahun 1983-2014. Penelitian ini mengunakan analisis informetrika terhadap seluruh artikel jurnal. Hasil penelitian menunjukkan: (1) distribusi artikel pada setiap volume terbitan Zoo Indonesia mengalami peningkatan dengan jumlah terakhir sebesar 6 artikel pada setiap volume terbitannya; (2) pola kepengarangan menunjukkan dominan oleh satu pengarang sebesar 46,08\%; dan (3) subjek penelitian yang paling banyak dibahas pada Zoo Indonesia adalah mengenai arthropoda sebesar 30,41\%. Kesimpulannya adalah Zoo Indonesia dalam perjalanannya terus berusaha meningkatkan kualitasnya sebagai majalah ilmiah dengan menerapkan sistem e-journal dan terus membenahi baik aspek fisik maupun sistem keredaksian di dalamnya.
\end{abstract}

Keywords: Zoo Indonesia; Informetric; Article distribution; Authorship; Research subject

\section{PENDAHULUAN}

Kegiatan penelitian sudah menjadi kewajiban bagi seseorang yang memilih jalan hidup menjadi fungsional peneliti. Di Indonesia, menurut data statistik peneliti per-Desember 2015 yang dimiliki oleh Pusbindiklat Peneliti LIPI ada sekitar 9308 peneliti yang berada di lembaga penelitian yang tersebar di seluruh kementerian dan non-kementerian di Indonesia. Namun, bukanlah tidak hanya peneliti yang 
melakukan penelitian saja karena di lembaga pendidikan pun berlangsung kegiatan penelitian oleh sivitas akademiknya. Sebagaimana yang dikutip dari Peraturan Kepala LIPI Nomor 08/E/2013 tentang Pedoman Klirens Etik Penelitian dan Publikasi Ilmiah, penelitian adalah kegiatan yang dilakukan secara sistematis, menurut kaidah dan metode ilmiah untuk memperoleh informasi, data dan keterangan yang berkaitan dengan pemahaman dan pembuktian kebenaran atau ketidakbenaran suatu asumsi dan/atau hipotesis di bidang ilmu pengetahuan dan teknologi serta menarik kesimpulan bagi keperluan kemajuan ilmu pengetahuan dan teknologi. Saat ini, kegiatan penelitian dalam bidang biologi, khususnya fauna termasuk yang paling diminati. Hal ini sebagaimana dikutip dari Harian Kompas tanggal 19 Januari 2016, bahwa selama tahun 2014, Kemenristek-Dikti mencatat bidang zoologi (9,77\%) sebagai urutan kedua setelah ekologi (15,43\%) selama tahun 2014 sebagai bidang yang diminati oleh peneliti asing ketika melakukan penelitian di Indonesia.

Suatu penelitian tidaklah berguna apabila tidak diketahui pihak lain. Oleh karena itu, hasil penelitian harus dipublikasikan, apakah dalam bentuk karya tulis ilmiah yang tertuang dalam jurnal, buku, prosiding, laporan penelitian, makalah dan poster ilmiah ataupun dalam format karya tulis semi-ilmiah atau populer. Selain sebagai upaya diseminasi, publikasi juga menjadi sarana penyebarluasan hasil-hasil penelitian kepada masyarakat ilmiah di Indonesia dan masyarakat ilmiah dunia. Meningkatnya jumlah publikasi hasil-hasil penelitian itu seharusnya juga diikuti oleh meningkatnya jumlah majalah ilmiah yang menampung karya tulis ilmiah hasil penelitian.

Zoo Indonesia adalah majalah ilmiah di bidang fauna tropika yang diterbitkan sejak tahun 1983 oleh organisasi profesi keilmiahan Masyarakat Zoologi Indonesia (MZI) dan bekerjasama dengan Bidang Zoologi, Pusat Penelitian Biologi LIPI. MZI adalah suatu organisasi profesi dengan anggota terdiri dari peneliti, pengajar, pemerhati, dan simpatisan kehidupan fauna tropika, khususnya fauna Indonesia. Kegiatan utama MZI adalah pemasyarakatan tentang ilmu kehidupan fauna tropika Indonesia, dalam segala aspeknya, baik dalam bentuk publikasi ilmiah, publikasi populer, pendidikan, penelitian, pameran, maupun pemantauan. Zoo Indonesia memuat tulisan hasil penelitian dan tinjauan ilmiah yang berhubungan dengan aspek fauna tropika, khususnya wilayah Indonesia dan Asia. Adapun publikasi ilmiah lainnya adalah berupa monograf yang terbit tidak menentu.

Sejalan dengan perkembangan peraturan mengenai jurnal ilmiah di lingkungan lembaga penelitian non-kementerian, Zoo Indonesia tidak terlepas dari keharusan untuk mengikuti perkembangan iptek yang ada. Sejak tahun penerbitan 2006, akreditasi yang pernah dikeluarkan Departemen Pendidikan untuk Zoo Indonesia (No. 69/DIKTI/Kep./2000) sementara waktu tidak diperpanjang kembali tetapi diganti dengan akreditasi yang dikeluarkan oleh Lembaga Ilmu Pengetahuan Indonesia, yaitu Pedoman Akreditasi Majalah Ilmiah melalui Peraturan Kepala LIPI No 01/E/2005. Hal ini sejalan dengan sejarah kelahiran organisasi profesi itu sendiri yang didukung oleh lembaga penelitian non-kementerian.

Saat ini, Zoo Indonesia berstatus terakreditasi berdasarkan SK Kepala LIPI No.625/E/2013. Berbagai penyesuaian terus dilakukan Zoo Indonesia, baik dalam hal susunan redaksi maupun secara fisik, seperti penyesuaian tata letak dan ukuran sampul depan, penomoran terbitan dan halaman yang mengikuti aturan baku, dan lainnya. Hal ini merupakan suatu keharusan mengingat semakin hari kriteria pengakuan suatu jurnal ilmiah semakin ketat.

Pentingnya studi informetrik sebagaimana dikutip Pendit (2013) bahwa pemanfaatannya semakin 
mengarah dengan konteks penelitian ilmiah yang lebih luas, yakni dalam hal kebijakan penelitian di sebuah masyarakat atau komunitas di mana sebuah perpustakaan berada. Sebagaimana yang terjadi di Inggris, menurut Joint (2008) hasil kajian bibliometrika digunakan sebagai bagian dari ukuran kinerja penelitian; di Jerman dan Belanda, menurut Neufeld dan Von Ins (2011) kajian bibliometrika dipakai untuk menyimak pola pemberian dana riset sehingga tentunya dapat dimanfaatkan bagi pengembangan kebijakan penelitian sebuah negara; dan Rigby (2012) menganjurkan agar kaitan antara jumlah sumber pendanaan dan citation impact terus dilakukan untuk memantau efisiensi dan efektivitas kegiatan penelitian di sebuah negara.

Penelitian terhadap pola kepengarangan dan kolaborasi penelitian dalam penelitian fauna pernah dilakukan Vimal dan Reddy (1996), yang mempelajari tren dalam pola kepengarangan dan kolaborasi dalam penelitian fauna dengan mengambil sampel dari 19323 jurnal yang disitasi dalam tesis mengenai penelitian fauna. Hasil penelitian menunjukkan bahwa meskipun penulis lebih dari satu dominan, namun penulis tunggal juga ada. Proporsi penulis tunggal telah menunjukkan kecenderungan menurun selama periode 1901-1995. Dapat diamati pula bahwa proporsi kepenulisan tunggal kemungkinan tidak signifikan setelah tahun 2030. Tingkat kerjasama dalam penelitian adalah 0,75 dalam penelitian fauna secara keseluruhan.

Berdasarkan paparan di atas terkait mengenai pentingnya keberadaan suatu jurnal ilmiah dan studi informetrika, maka penulis tertarik untuk meneliti perkembangan jurnal fauna tropika Zoo Indonesia selama rentang waktu 1983-2014 dengan metode informetrika dilihat dari distribusi artikel, pola kepengarangan, dan subjek penelitian.

\section{TINJAUAN PUSTAKA}

Studi mengenai informetrika disampaikan Prof. Otto Nacke pada tahun 1979, namun konsepnya menjadi populer sejak berlangsungnya konferensi internasional pertama mengenai informaterika pada tahun 1987. Informetrika muncul terutama karena ketidakmampuan disiplin yang ada, seperti bibliometrika dan scientometrics untuk menggolongkan secara komprehensif pandangan matematika pada masalah di daerah informasi ilmu pengetahuan. Secara umum, informetrika mencakup kajian terhadap aspek kuantitatif informasi dalam bentuk apapun termasuk catatan, bibliografi, kelompok sosial dan ilmuwan.

Tague-Sutcliffe dalam Das (2013) memperluas lingkup dari informetrika dengan menambahkan dua fenomena: (a) definisi dan pengukuran informasi; dan (b) jenis dan karakteristik pengukuran kinerja temu kembali informasi. Dengan demikian, dapat mengakomodasi dan memanfaatkan banyak studi tentang pengukuran informasi. Kemudian Egghe dalam Das (2013) secara komprehensif mengatakan bahwa "informetrics is the generic-term encompassing all -metrics studies related to the information science, including bibliometrics (bibliographies, libraries, ...), scientometrics (science policy, citation analysis, research evaluation, ...). Webometrics (metrics of the web, the internet or other social networks such as citation or collaboration networks), ...”. Jadi, informetrika adalah studi tentang aspek-aspek kuantitatif informasi yang meliputi produksi, diseminasi, temu kembali, dan pengukuran informasi, terlepas dari apapun bentuk atau asalnya.

Berikut ini dipaparkan tinjauan pustaka mengenai perkembangan studi informetrika dalam bidang 
ilmu informasi dan perpustakaan yang disarikan dari artikel Journal of Informetrics a Bibliometric Profile oleh Prabir Kumar Das (2013). Studi Bibliometrik terhadap jurnal bidang ilmu perpustakaan dan informasi sangat beragam, ditemukan bahwa setengah dari total literatur ilmu informasi adalah studi bibliometrik dan mayoritas dari mereka adalah studi penggunaan informasi umumnya dalam bentuk survei dan analisis kutipan. Kajian berikutnya dilakukan Tiew (1997), dikemukakan bahwa ada 40 studi (dari 102) tentang studi karakteristik jurnal. Young (2006) melaporkan studi berdasarkan Library Quarterly (LQ) untuk mengidentifikasi jumlah publikasi; daftar peringkat penulis; yang paling sering dikutip penulis LQ dan artikel di WoS. Kemudian, Verma, et al. (2007) menganalisis 131 artikel dari Annals of Library \& Information Studies selama 1999-2005 untuk meneliti kebijakan tahun, kebijakan kelembagaan, pernyataan kebijakan dalam distribusi kontribusi, pola kepengarangan, analisis kutipan, panjang kontribusi dan sebagainya.

Singh, et al. (2007) mempelajari pertumbuhan dan karakteristik literatur perpustakaan digital berdasarkan lebih dari 1000 artikel yang dari diambil dari LISA ditambah kemunculannya selama tahun 1998 sampai 2004. Bakri \& Willett (2008) memperbaharui penelitian sebelumnya dari Tiew, et al. (2002) untuk mengidentifikasi perubahan yang signifikan dari perilaku ilmiah dalam jurnal. Park (2008) meneliti karakteristik kepengarangan dari top 20 jurnal LIS dari wilayah Asia dan Pasifik berdasarkan data WoS selama 1967-2005. Mukerjee (2009) mengkaji Journal of American Society for Information Science and Technology untuk menunjukkan pertumbuhan artikel, pola kepengarangan, kolaborasi, dispersi geografis, sifat dikutip dan mengutip referensi, penulis produktif dan penulis yang banyak dikutip, dll. Halder \& Chandra (2009) menyoroti perkembangan jurnal, pola kepengarangan, tren subjek, distribusi referensi, ilustrasi dan pernyataan kebijakan distribusi dari kontributor artikel yang muncul dalam IASLIC Buletin selama tahun 2003 untuk 2007. Dalam sebuah review, Zainab, et al. (2009) melaporkan 11 studi bibliometrik pada jurnal LIS . Thanuskodi (2010) mempelajari Library Philosophy and Practice tahun 2005-2009 untuk melaporkan bahwa mayoritas artikel oleh pengarang tunggal dan aplikasi komputer pada LIS adalah wilayah dominan penelitian.

Berbagai elemen kepenulisan, yaitu, penulis paling produktif, afiliasi mereka dan distribusi geografis, dll, dari D-Lib Magazine diselidiki oleh Park (2010). Kemudian, Journal of Documentation yang ditinjau kembali oleh Tsay \& Shu (2011) mengeksplorasi berbagai karakteristik bibliometrik. Dari studi tentang Electronic Library Journal, Hussain, et al. (2011) menunjukkan bahwa sebagian besar artikel penulinya tunggal sebagaimana tingkat kolaborasi sangat rendah $(0,256)$; mayoritas penulisnya adalah pustakawan, dosen atau peneliti yang berafiliasi dengan lembaga-lembaga yang lebih tinggi. Thanuskodi (2011) mempelajari Library Herald Journal dan melaporkan bahwa sebagian besar kontribusi adalah penulis tunggal; artikel jurnal merupakan saluran utama komunikasi, dan menerima maksimum kutipan. Sing, et al. (2011) meringkas mengenai tren publikasi, pola kepengarangan dan dispersi geografis kontributor dari DESIDOC Bulletin of Information Technology. Pada tahun yang sama, Kumar \& Moorthy (2011) mempelajari DESIDOC Bulletin of Information Technology periode 2001-2010 untuk mengeksplorasi perkembangan jurnal dan pola kepengarangan, cakupan konten dan distribusi subjek. Egghe (2012) telah melaporkan profil singkat dengan gambaran yang baik terhadap Journal of Informetrics melalui komunikasi pendek tetapi analisis yang detail. Penelitian mengenai informetrika terus berkembang sampai saat ini dalam beragam bidang ilmu, ruang lingkup, kepentingan, dan lainnya. 
Kemudian, menurut Guns (2013), pada tahap tertinggi, studi informetrika mempelajari entitas dan hubungan dari tiga dimensi: dokumen, dimensi sosial (orang dan kelompok orang), dan dimensi epistemik atau kognitif (topik dan ide), dengan demikian studi informetrika yang dilakukan akan lebih lengkap.

\section{METODE}

Penelitian ini menggunakan analisis informetrik. Menurut De Bellis dalam Ngoepe (2013) menjelaskan bahwa informetrics is the quantitative study of information production, storage, retrieval, dissemination, and utilisation. Beck \& Manuel dalam Ngoepe (2013), menjelaskan bahwa informetrics is unobtrusive because its focus is on the products of human activity (eg reports, books, articles,w eb pages, and so forth) and not on humans. Dalam penelitian ini, penulis mengumpulkan data berupa seluruh artikel dalam terbitan Zoo Indonesia 1983-2014. Data yang terkumpul kemudian dibagi menjadi empat periode waktu, yakni: 1983-1990; 1991-2000; 2001-2010; dan 2011-2014, kemudian dijabarkan dari aspek distribusi artikel, pola kepengarangan, dan subjek artikelnya.

Sementara itu, untuk menentukan subjek artikel, penulis menggunakan klasifikasi hewan menurut Carolus Linnaeus. Klasifikasi (pengelompokan) merupakan suatu cara memilah dan mengelompokkan makhluk hidup menjadi golongan atau unit tertentu. Berdasarkan klasifikasi pada filum (kelas) utama, hewan terbagi menjadi dua kelompok besar yakni, vertebrata (bertulang belakang) dan invertebrata (tak bertulang belakang). Dari kelompok invertebrata, dibagi menjadi: protozoa, porifera, cnidaria, stenophora, platyhelminthes, nematoda, annelida, mollusca, dan arthropoda. Sedangkan dari kelompok vertebrata, dibagi menjadi: ikan, amfibi, reptilia, burung, dan mamalia.

\section{HASIL DAN PEMBAHASAN}

\subsection{Distribusi Artikel}

\section{Periode 1: Tahun 1983-1990}

Tabel 1 menunjukkan bahwa total artikel pada periode ini berjumlah 13 artikel. Pada periode pertama, terbitan tahun 1983-1990, terlihat Zoo Indonesia masih belum konsisten dengan terbitannya, pada tahun pertama terbit setahun dua kali, namun tahun berikutnya tidak ada terbitan. Setelah tahun 1986, tahun 1987 hanya terbit satu nomor dalam setahun namun memuat dua artikel, lalu terhenti kembali pada tahun 1988. Terbit kembali tahun 1989 dengan satu nomor berisi dua artikel. Akhir periode ini, pada tahun 1990, Zoo Indonesia kembali terbit dengan setahun dua nomor dan pada nomor 10 memuat dua artikel.

Tabel 1. Distribusi Artikel pada Periode 1

\begin{tabular}{|c|c|c|}
\hline Tahun & Nomor & Jumlah Artikel \\
\hline 1983 & 1 & 1 \\
1983 & 2 & 1 \\
1985 & 3 & 1 \\
\hline
\end{tabular}


BACA: Jurnal Dokumentasi dan Informasi, 37 (1) Juni 2016, Halaman : 25-40

\begin{tabular}{|l|l|l|}
\hline 1985 & 4 & 1 \\
1986 & 5 & 1 \\
1986 & 6 & 1 \\
1987 & 7 & 2 \\
1989 & 8 & 2 \\
1990 & 9 & 1 \\
1990 & 10 & 2 \\
\hline \multicolumn{2}{|c|}{ Total } & $\mathbf{1 3}$ \\
\hline
\end{tabular}

\section{Periode 2: Tahun 1991-2000}

Tabel 2 menunjukkan bahwa total artikel pada periode ini berjumlah 37 artikel. Pada periode kedua, telihat Zoo Indonesia sudah lebih konsisten dengan adanya terbitan pada setiap tahunnya dan setiap nomor memuat dua artikel, kecuali pada tahun 1993 nomor 22 hanya memuat satu artikel. Namun terbitan Zoo Indonesia terlihat tidak konsisten pada pembagian nomor terbitan dalam setahunnya karena pada tahun 1992 ada 4 nomor terbit, dan pada tahun 1993 ada 6 nomor terbit.

Tabel 2. Distribusi Artikel pada Periode 2

\begin{tabular}{|c|c|c|}
\hline Tahun & Nomor & Jumlah Artikel \\
\hline 1991 & 11 & 2 \\
1991 & 12 & 2 \\
1992 & 13 & 2 \\
1992 & 14 & 2 \\
1992 & 15 & 2 \\
1992 & 16 & 2 \\
1993 & 17 & 2 \\
1993 & 18 & 2 \\
1993 & 19 & 2 \\
1993 & 20 & 2 \\
1993 & 21 & 2 \\
1993 & 22 & 1 \\
1994 & 23 & 2 \\
1994 & 24 & 2 \\
1995 & 25 & 2 \\
1995 & 26 & 2 \\
1996 & 27 & 2 \\
1996 & 28 & 2 \\
1997 & 29 & 2 \\
\hline \multicolumn{2}{|c|}{ Total } & 37 \\
\hline
\end{tabular}




\section{Periode 3: Tahun 2001-2010}

Tabel 3 menunjukkan bahwa total artikel pada periode ini berjumlah 56 artikel. Pada periode ketiga, setelah sempat vakum selama 3 tahun, Zoo Indonesia kembali terbit pada tahun 2001 dengan memuat 6 artikel. Sangat disayangkan baru terbit sekali, Zoo Indonesia kembali vakum selama 4 tahun (2002-2005). Zoo Indonesia kembali terbit pada tahun2006 dengan melakukan beberapa penyesuaian terkait adanya Pedoman Akreditasi Majalah Ilmiah melalui Peraturan Kepala LIPI No 01/E/2005.

Tabel 3. Distribusi Artikel pada Periode 3

\begin{tabular}{|c|c|c|c|}
\hline Tahun & Volume & Nomor & JumlahArtikel \\
\hline 2001 & 28 & & 6 \\
\hline 2006 & 15 & 1 & 5 \\
& 15 & 2 & 5 \\
\hline 2007 & 16 & 1 & 5 \\
& 16 & 2 & 5 \\
\hline 2008 & 17 & 1 & 5 \\
& 17 & 2 & 5 \\
\hline 2009 & 18 & 1 & 5 \\
& 18 & 2 & 5 \\
\hline 2010 & 19 & 1 & 5 \\
& 19 & 2 & 5 \\
\hline
\end{tabular}

\section{Periode 4: Tahun 2011-2014}

Tabel 4 menunjukkan bahwa total artikel pada periode ini berjumlah 42 artikel. Pada periode keempat, Zoo Indonesia terus berusaha memperbaiki kualitas seiring dengan tuntutan diakuinya suatu majalah ilmiah juga beratnya persyaratan akreditasi yang harus dijalani, apalagi ke depannya harus menerapkan e-journal, bahkan akreditasi pun nantinya akan dilakukan secara online.

Tabel 4. Distribusi Artikel pada Periode 4

\begin{tabular}{|c|c|c|c|}
\hline Tahun & Volume & Nomor & Jumlah Artikel \\
\hline 2011 & 20 & 1 & 5 \\
& 20 & 2 & 5 \\
\hline 2012 & 21 & 1 & 5 \\
& 21 & 2 & 5 \\
\hline 2013 & 22 & 1 & 5 \\
& 22 & 2 & 5 \\
\hline 2014 & 23 & 1 & 6 \\
\hline
\end{tabular}




\begin{tabular}{|c|c|c|c|}
\hline & 23 & 2 & 6 \\
\hline \multicolumn{3}{|c|}{ Total } & 42 \\
\hline
\end{tabular}

Data pada Tabel 1 sampai dengan Tabel 4 menunjukkan bahwa jumlah keseluruhan artikel Zoo Indonesia pada 1983-2004 adalah 148 aritkel. Kemudian, distribusi artikel Zoo Indonesia secara keseluruhan akan terlihat pada grafik 1 berikut ini.

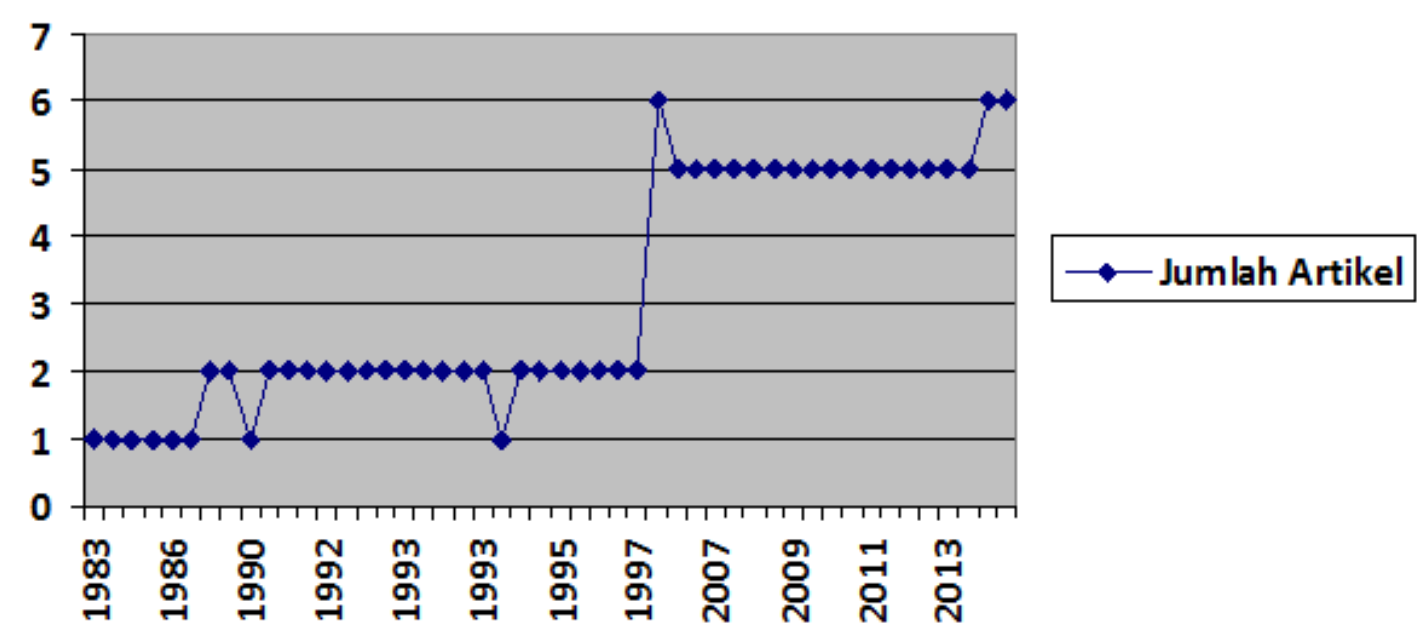

Grafik 1. Distribusi artikel periode 1-4

Dari Grafik 1 terlihat bahwa Zoo Indonesia terus meningkatkan jumlah artikel pada setiap terbitannya. Meningkatnya apresiasi dan kepercayaan peneliti terhadap Zoo Indonesia diketahui penulis dari data ketersediaan naskah yang dimiliki redaksi, yakni banyaknya naskah yang masuk setiap tahunnya selalu lebih dari 10 naskah terutama sejak tahun 2011, sehingga pada tahun 2014 dewan redaksi menetapkan artikel pada setiap terbitan adalah sebanyak 6 buah.

Pada Periode 1 dan 2 sebelum mengikuti pedoman akreditasi majalah ilmiah, Zoo Indonesia terbit tidak menentu dan juga tidak konsisten dengan jumlah artikel pada setiap terbitannya. Setelah penulis melakukan wawancara dengan Prof. Dr. Gono Semiadi yang pernah menjadi salah satu dewan redaksi juga terus memantau perkembangan Zoo Indonesia sampai dengan saat ini, menyampaikan beberapa hal terkait Zoo Indonesia, yakni:

"Sebelum terbitan tahun 2006, Zoo Indonesia penomorannya menggunakan nomor urut, setelah adanya Pedoman Akreditasi Majalah Ilmiah melalui Peraturan Kepala LIPI No 01/E/2005, ada ketentuan bahwa terbitan jurnal harus mencantumkan keterangan volume dan nomor urut karenanya berdasarkan kesepakatan dewan redaksi pada saat itu, terbitan Zoo Indonesia tahun 2006 mencantumkan keterangan volume 15 dan terbit setahun dua kali (dua nomor urut), alasan yang mendasarinya adalah asumsi terbitan terakhir pada 2001 menggunakan nomor urut 28 maka dianggap sepadan telah terbit 14 volume (asumsi setahun 2 kali terbitan). Sebelum adanya pedoman akreditasi majalah ilmiah tahun 2005, terbitan bersifat irregular artinya tidak menentu juga tidak ada batas minimum artikel, sehingga apabila ada satu artikel 
pun dapat diterbitkan.Terbitan Zoo Indonesia sebelum adanya pedoman akreditasi majalah ilmiah tahun 2005, cenderung berfungsi terutama sebagai fasilitator bagi pemenuhan angka kredit peneliti dari bidang zoologi Pusat Penelitian Biologi-LIPI, kemudian berfungsi sebagai diseminasi karya ilmiah peneliti dan sebagai media komunikasi. Terbitan Zoo Indonesia sempat terhenti pada tahun 1998-2000 dikarenakan krisis moneter yang berimbas pada tiadanya pendanaan untuk terbitan”.

\subsection{Pola Kepengarangan}

\section{Periode 1: Tahun 1983-1990}

Tabel 5 menunjukkan bahwa pola kepengarangan tunggal sebesar 38,46\% sedangkan sisanya adalah kolaborasi baik dua atau lebih pengarang sebesar 61,53\%.

Tabel 5. Pola Kepengarangan pada Periode 1

\begin{tabular}{|c|c|c|}
\hline Jumlah Penulis & Jumlah & Prosentase \\
\hline 1 & 5 & $38,46 \%$ \\
\hline 2 & 6 & $46,15 \%$ \\
\hline 3 & 1 & $7,69 \%$ \\
\hline$>3$ & 1 & $7,69 \%$ \\
\hline & 13 & $100 \%$ \\
\hline
\end{tabular}

\section{Periode 2: Tahun 1991-2000}

Tabel 6 menunjukkan bahwa pola kepengarangan tunggal sebesar 45,95\% sedangkan sisanya adalah kolaborasi baik dua atau lebih pengarang sebesar 54,06\%.

Tabel 6. Pola Kepengarangan pada Periode 2

\begin{tabular}{|c|c|c|}
\hline JumlahPenulis & Jumlah & Prosentase \\
\hline 1 & 17 & $45,95 \%$ \\
2 & 15 & $40,54 \%$ \\
3 & 2 & $5,41 \%$ \\
$>3$ & 3 & $8,11 \%$ \\
\hline \multicolumn{2}{|c|}{} & $\mathbf{1 0 0} \%$ \\
\hline
\end{tabular}

Kolaborasi pada periode 1 dan 2, lebih besar persentasenya karena bila dilihat dari data penelitinya maka dapat diketahui para peneliti tersebut pada periode 1 dan 2 istilahnya belum mapan dalam keilmuannya sehingga mereka membutuhkan kolaborasi dengan peneliti lain baik dari lembaga sendiri maupun lembaga lainnya di luar Pusat Penelitian Biologi LIPI. Kolaborasi menurut Sooryamoorthy (2013) dapat dianalisis dalam berbagai cara, ketika penulis sama-sama berasal dari suatu negara, itu dianggap sebagai kolaborasi dalam negeri, baik kelembagaan-internal (penulis dalam satu departemen atau lembaga yang sama) atau kelembagaan- eksternal (penulis berada dalam departemen atau lembaga berbeda). Kolaborasi internasional berarti bahwa 
setidaknya salah satu kolaborator adalah dari negara yang lain. Jika lebih dari satu negara lain yang terlibat, maka itu menjadi kerjasama internasional multi-negara. Publikasi hasil kolaborasi bisa berupa domestik, internasional, atau keduanya.

\section{Periode 3: Tahun 2001-2010}

Tabel 7 menunjukkan bahwa pola kepengarangan tunggal sebesar 66,07\% sedangkan sisanya adalah kolaborasi baik dua atau lebih pengarang sebesar 33,92\%.

Tabel 7. Pola Kepengarangan pada Periode 3

\begin{tabular}{|c|c|c|}
\hline Penulis & Jumlah & Prosentase \\
\hline 1 & 37 & $66,07 \%$ \\
\hline 2 & 5 & $8,92 \%$ \\
\hline 3 & 8 & $14,29 \%$ \\
\hline$>3$ & 6 & $10,71 \%$ \\
\hline & 26 & $100 \%$ \\
\hline
\end{tabular}

\section{Periode 4: Tahun 2011-2014}

Tabel 8 menunjukkan pola kepengarangan tunggal sebesar 57,14\% sedangkan sisanya adalah kolaborasi baik dua atau lebih pengarang sebesar 42,86\%.

Tabel 8. Pola Kepengarangan pada Periode 4

\begin{tabular}{|c|c|c|}
\hline Penulis & Jumlah & Prosentase \\
\hline 1 & 24 & $57,14 \%$ \\
\hline 2 & 7 & $16,67 \%$ \\
\hline 3 & 6 & $14,29 \%$ \\
\hline$>3$ & 5 & $11,90 \%$ \\
\hline & 42 & $100 \%$ \\
\hline
\end{tabular}

Kepengarangan tunggal pada periode 3 dan 4, lebih besar persentasenya karena bila dilihat data penelitinya maka dapat diketahui para peneliti tersebut pada periode 3 dan 4 istilahnya sudah mapan dalam keilmuannya sehingga mereka lebih percaya diri dalam karya tulis ilmiah tanpa kerjasama dengan peneliti lainnya.

Berdasarkan tabel 5 sampai dengan tabel 8, diperoleh data gabungan sebagaimana terlihat pada Tabel 9.

Tabel 9. Pola Kepengarangan pada Zoo Indonesia

\begin{tabular}{|c|c|c|}
\hline Penulis & Jumlah & Prosentase \\
\hline 1 & 83 & $56,08 \%$ \\
2 & 33 & $22,29 \%$ \\
\hline
\end{tabular}




\begin{tabular}{|c|c|c|}
\hline 3 & 17 & $11,49 \%$ \\
\hline$>3$ & 15 & $10,16 \%$ \\
\hline & 42 & $100 \%$ \\
\hline
\end{tabular}

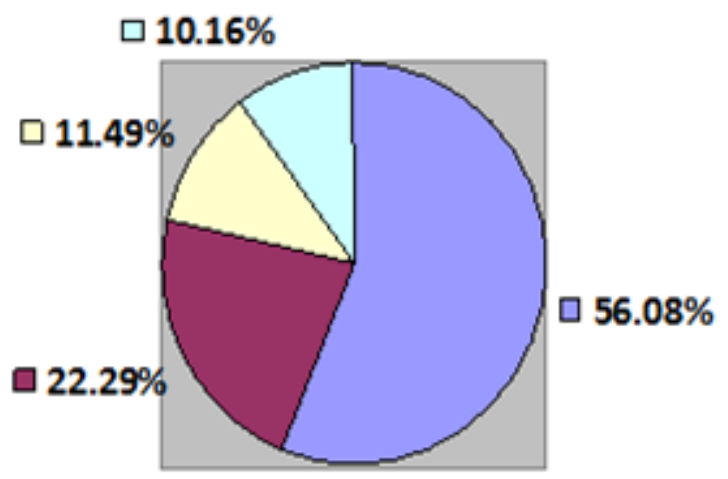

\section{$\square 1$ Pengarang $\square 2$ Pengarang $\square 3$ Pengarang $\square>3$ Pengarang}

Grafik 2. Pola Kepengarangan pada Zoo Indonesia

Dari grafik 2 terlihat bahwa dari analisis informetrika terhadap artikel mengenai pola kepengarangan secara keseluruhan adalah dominan oleh satu pengarang sebesar 56,08\%, Meskipun di atas sudah dijelaskan sebenarnya dominan kepengarangan tunggal ini ada di periode 3 dan 4, di mana peneliti sudah merasa mapan dengan keimuannya sehingga percaya diri untuk menulis karya ilmiah sendiri. Besarnya prosentase pengarang tunggal ini juga dikarenakan pada periode 3 dan 4 jumlah artikel lebih banyak dibanding periode 1 dan 2, hal ini dikarenakan sudah adanya standar minimum jumlah artikel dan juga keteraturan dalam terbitan Zoo Indonesia. Alasan lain kepengarangan tunggal dominan adalah dengan meninjau Peraturan Kepala LIPI Nomor 02/E/ 2005 tentang Petunjuk Teknis Jabatan Fungsional Peneliti, pada bab pendahuluan, poin 2.1.2.3 dikatakan bahwa:

"Karya Tulis Ilmiah (KTI) yang ditulis dalam bentuk makalah oleh lebih dari seorang, maka pembagian angka kreditnya ditetapkan: $60 \%$ bagi penulis utama dan $40 \%$ untuk penulis kedua. Jika KTI ditulis oleh 3 orang, pembagian angka kreditnya: 50\% untuk penulis pertama, dan masing masing 25\% untuk penulis kedua dan ketiga; Jika KTI ditulis oleh 4 orang, pembagian angka kreditnya: 40\% untuk penulis pertama dan 20\% untuk masing-masing penulis dibagi sama rata di antara semua penulis pembantu. Jika penulis lebih dari ketentuan tersebut, $40 \%$ untuk penulis pertama dan sisanya dibagi sama rata di antara penulis pembantu”.

Berdasarkan pernyataan di atas, peneliti cenderung pada pola kepengarangan tunggal karena tentu akan memperoleh angka kredit 100\%, yakni sebesar 25 apabila membuat karya tulis ilmiah yang terbit jurnal ilmiah nasional yang terakreditasi seperti Zoo Indonesia sehingga peneliti akan memperoleh angka kredit cukup besar dibanding berkolaborasi pada saat pengajuan fungsional.

Pola kepengarangan tunggal yang dominan ini juga terlihat dari tiga hasil penelitian berikut. Verma et al. dalam Pandita (2014) melakukan analisis bibliometrik terhadap 131 artikel yang dipublikasikan jurnal ALIS selama periode 1999-2005, dan menemukan bahwa kepengarangan tunggal lebih besar daripada kolaborasi. Mittal at al dalam Pandita (2014,) dalam studinya terhadap 
Library and Information Science Education menemukan bahwa 72.7\% artikel merupakan kontribusi dari pengarang tunggal, dan 20,69\% oleh dua pengarang. Sementara itu, Sooryamoorthy (2013) yang melakukan studi scientometric terhadap hasil penelitian dalam bidang sains di Afrika Selatan tahun 1975-2005, pola kepengarangannya menunjukkan sekitar seperlima dari publikasi antara tahun 1975 dan 2005 dilakukan oleh penulis tunggal.

\subsection{Subjek Artikel}

Berdasarkan klasifikasi hewan secara umum tersebut, analisis subjek dalam artikel dilihat terlebih dahulu dari objek utamanya dalam artikel tersebut dan kemudian dimasukkan ke dalam klasifikasi hewan berdasarkan kelas utamanya.

\section{Periode 1: Tahun 1983-1990}

Tabel 10 menunjukkan bahwa subjek arthropoda yang paling banyak diteliti sebesar 38,46\%, dikuti subjek ikan 30,77\% dan yang ketiga adalah mollusca sebesar 15,38\%.

Tabel 10. Daftar Subjek Artikel pada Periode 1

\begin{tabular}{|c|c|c|}
\hline Subjek & Artikel & Prosentase \\
\hline Annelida & 1 & $7,69 \%$ \\
\hline Mollusca & 2 & $15,38 \%$ \\
\hline Arthropoda & 5 & $38,46 \%$ \\
\hline Ikan (Pisces) & 4 & $30,77 \%$ \\
\hline & 13 & $100 \%$ \\
\hline
\end{tabular}

\section{Periode 2: Tahun 1991-2000}

Tabel 11 menunjukkan bahwa subjek arthropoda yang paling banyak diteliti sebesar 29,73\%, dikuti subjek mammalia 21,62\%, dan ketiga adalah subjek burung dan reptil sama-sama memperoleh persentase sebesar $13,51 \%$.

Tabel 11. Daftar Subjek Artikel pada Periode 2

\begin{tabular}{|l|c|c|}
\hline Subjek & Artikel & Prosentase \\
\hline Protozoa & 1 & $2,70 \%$ \\
Platyhelminthes & 1 & $2,70 \%$ \\
Mollusca & 3 & $8,11 \%$ \\
Arthropoda & 11 & $29,73 \%$ \\
Ikan (Pisces) & 2 & $5,41 \%$ \\
Reptil & 5 & $13,51 \%$ \\
Burung (Aves) & 5 & $13.51 \%$ \\
Mammalia & 8 & $21,62 \%$ \\
\hline
\end{tabular}




\begin{tabular}{|l|c|c|}
\hline Lain-lain & 1 & $2,72 \%$ \\
\hline & 37 & $100 \%$ \\
\hline
\end{tabular}

\section{Periode 3: Tahun 2001-2010}

Tabel 12 menunjukkan bahwa subjek arthropoda yang paling banyak diteliti sebesar 38,46\%, dikuti subjek ikan 30,77\% dan yang ketiga adalah mollusca sebesar 15,38\%.

Tabel 12. Daftar Subjek Artikel pada Periode 3

\begin{tabular}{|c|c|c|}
\hline Subjek & Artikel & Prosentase \\
\hline Porifera & 2 & $3,57 \%$ \\
\hline Arthropoda & 17 & $30,36 \%$ \\
\hline Ikan (Pisces) & 7 & $1,25 \%$ \\
\hline Amfibi & 8 & $14,29 \%$ \\
\hline Reptil & 6 & $10,71 \%$ \\
\hline Burung (Aves) & 3 & $53,6 \%$ \\
\hline Mammalia & 11 & $19,64 \%$ \\
\hline Lain-lain & 2 & $3,57 \%$ \\
\hline & 56 & $100 \%$ \\
\hline
\end{tabular}

\section{Periode 4: Tahun 2011-2014}

Tabel 13 menunjukkan bahwa subjek arthropoda yang paling banyak diteliti sebesar 28,57\%, dikuti subjek mammalia 23,81\%, dan ketiga adalah burung sebesar 14,29\%.

Tabel 13. Daftar Subjek Artikel pada Periode 4

\begin{tabular}{|l|c|c|}
\hline Subjek & Artikel & Persentase \\
\hline Annelida & 1 & $2,38 \%$ \\
Mollusca & 3 & $7,14 \%$ \\
Arthropoda & 12 & $28,57 \%$ \\
Ikan (Pisces) & 5 & $11,90 \%$ \\
Amfibi & 2 & $4,76 \%$ \\
Reptil & 2 & $4,76 \%$ \\
Burung (Aves) & 6 & $14,29 \%$ \\
Mammalia & 10 & $23,81 \%$ \\
Lain-lain & 1 & $2,38 \%$ \\
\hline \multicolumn{2}{|c}{} \\
\hline
\end{tabular}

Dari Tabel 14 terlihat subjek arthropoda yang paling banyak diteliti sebesar 30,41\%, dikuti 
subjek mammalia 19,59\%, dan yang ketiga adalah ikan sebesar 12,16\%.

Tabel 14. Daftar Subjek Artikel Zoo Indonesia

\begin{tabular}{|l|c|c|}
\hline Subjek & Artikel & Prosentase \\
\hline Protozoa & 1 & $0,68 \%$ \\
Porifera & 2 & $1,35 \%$ \\
Platyhelminthes & 1 & $0,68 \%$ \\
Annelida & 2 & $1,35 \%$ \\
Mollusca & 8 & $5,41 \%$ \\
Arthropoda & 45 & $30,41 \%$ \\
Ikan (Pisces) & 18 & $12.16 \%$ \\
Amfibi & 10 & $6,76 \%$ \\
Reptil & 13 & $8,78 \%$ \\
Burung (Aves) & 15 & $10,14 \%$ \\
Mammalia & 29 & $19,59 \%$ \\
Lain-lain & 4 & $2,70 \%$ \\
\hline \multicolumn{2}{|c|}{} \\
\hline
\end{tabular}
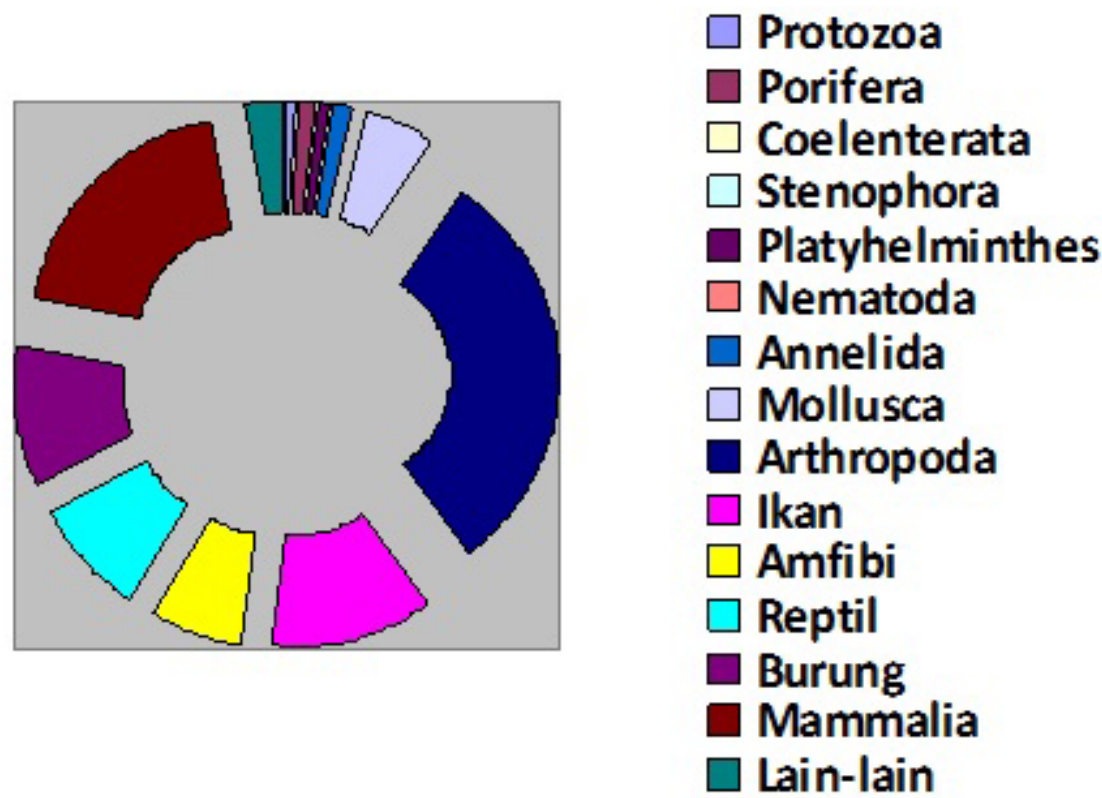

Grafik 3. Subjek artikel Zoo Indonesia

Berdasarkan Tabel 14 dan Grafik 3, terlihat bahwa urutan sepuluh teratas subjek artikel pada Zoo Indonesia, adalah:

1) Arthropoda, sebesar 30,41\%;

2) Mammalia, sebesar 19,59\%;

3) Ikan, sebesar $12,16 \%$;

4) Burung, sebesar 10,14\%; 
5) Reptil, sebesar 8,78\%;

6) Amfibi, sebesar 6,76\%;

7) Mollusca, sebesar 5,41\%;

8) Lain-lain, sebesar 2,70\%;

9) Porifera, sebesar 1,35\%;

10) Protozoa, sebesar $0,68 \%$.

Hasil di atas sesuai pernyataan yang dikutip dari Encyclopaedia Britannica (2016) bahwa arthropoda merupakan filum yang paling besar dalam dunia hewan dimana sekitar 84\% dari semua spesies yang dikenal hewan adalah anggota filum ini. Arthropoda terwakili di setiap habitat di bumi dan menunjukkan berbagai macam adaptasi. Beberapa jenis hidup di lingkungan perairan, dan lain-lain berada dalam lingkungan darat; beberapa kelompok bahkan beradaptasi dengan cara terbang melayang. Berdasarkan wawancara dengan Prof. Dr. Gono Semiadi, arthropoda merupakan filum yang memiliki jenis paling banyak karenanya membutuhkan jumlah peneliti yang lebih banyak, sehingga hal ini berdampak pula pada penelitian dengan subjek artikel mengenai arthropoda yang paling banyak ditemui dalam terbitan Zoo Indonesia.

Zoo Indonesia tidak memberikan aturan bahwa dalam setiap terbitan prioritas subjek penelitian mana yang harus ada, setiap naskah yang masuk berpeluang masuk dalam terbitan namun tergantung dari proses naskah mana yang terlebih dahulu selesai perbaikan dari penulis kemudian dinyatakan siap diterbitkan oleh redaksi Zoo Indonesia, pengecualian adalah apabila dalam proses terbitan ada 2 sampai tiga naskah dengan subjek yang sama, maka prioritas diberikan kepada naskah yang submit terlebih dahulu.

\section{KESIMPULAN}

Kesimpulan penelitian ini sebagai berikut: (1) distribusi artikel pada Zoo Indonesia terus mengalami peningkatan, dengan jumlah artikel terakhir pada setiap volumenya di tahun 2014 adalah sebanyak 6 artikel; (2) pola kepengarangan menunjukkan bahwa kepengarangan satu orang yang dominan sebesar 56,08\%; (3) subjek artikel menunjukkan bahwa artikel mengenai arthropoda yang paling banyak dibahas pada Zoo Indonesia sebesar 30,41\%; dan (4) kontribusi penelitian ini adalah apabila dilakukan pengkajian lebih mendalam terkait tiga dimensi dalam studi informetrika, maka dapat memetakan penelitian fauna di Indonesia dan kebijakan lembaga mengenai anggaran penelitian.

\section{SARAN DAN UCAPAN TERIMA KASIH}

Berdasarkan penelitian maupun pengamatan penulis selama tahun 2013 sampai dengan 2015 maka saran yang diberikan untuk meningkatkan kualitas Zoo Indonesia adalah: (1) terus meningkatkan jumlah artikel namun tetap memperhatikan kualitas dalam setiap terbitannya; (2) perlunya kerjasama yang baik antara redaksi, reviewer, penulis, dan stakeholder agar penerbitan berjalan tertib; (3) sebaiknya penulis tidak dominan dari Pusat Penelitian Biologi LIPI, namun juga dari lembaga lain (hal ini perlu upaya promosi agar penulis dari lembaga di luar MZI dan LIPI tertarik untuk memasukkan 
naskah ke Zoo Indonesia); (4) tertib administrasi baik dari redaksi maupun penyimpanan arsip jurnal yang telah terbit; (5) berusaha menerapkan e-journal dalam prosesnya apalagi terkait dengan akan diterapkannya akreditasi secara online melalui database Arjuna; dan (6) penelitian ini diharapkan membuka jalan bagi penelitian lebih lanjut dan lengkap pada Zoo Indonesia pada khususnya maupun jurnal lainnya pada umumnya, karena dimensi lainnya terkait studi informetrika masih banyak yang belum dibahas dalam artikel ini. Ucapan terima kasih penulis sampaikan kepada jajaran redaksi Zoo Indonesia juga Forkawan (Forum Pustakawan LIPI Bogor, Cibinong, dan Cibodas), dan rekan-rekan kuliah atas semua kerjasamanya selama ini.

\section{DAFTAR PUSTAKA}

Barnes, Robert D. 2016. “Arthropod”. (http://www.britannica.com/animal/arthropod, diakses 20 April 2016).

Das, Prabir Kumar. 2013. Journal of Informetrics: a Bibliometric Profile. DESIDOC Journal of Library \& Information Technology, 33(3), 243-252.

Guns, Raf. 2013. The Three Dimensions of Informetrics: a Conceptual View. Journal of Documentations, 69 (2), 295-308.

Lembaga Ilmu Pengetahuan Indonesia. 2005. Petunjuk Teknis Jabatan Fungsional Peneliti dan Angka Kreditnya. Jakarta: LIPI.

LIPI. 2013. Peraturan Kepala LIPI Nomor 08/E/2013 tentang Pedoman Klirens Etik Penelitian dan Publikasi ilmiah. Cibinong: Pusbindiklat, LIPI.

Ngoepe, Mpho \& Patrick Ngulube. 2013. Contribution of Record-Keeping to Audit Opinions: An Informetrics Analysis of The General Reports on Audit Outcomes of The Auditor-General of South Africa. Esarbica Journal, 32, 45-54.

NN. 2016. "Bidang Biologi Primadona Asing”. Kompas, Selasa, 19 Januari, hlm. 14, Kolom 4. Jakarta.

Pandita, Ramesh. 2014. DESIDOC Journal of Library and Information Technology (DJLIT): a biliometric study (2003-12). Library Philosophy and Practice, Paper 1038.

Pendit, Putu Laxman. 2013. “Open Access dan Kepustakawanan Indonesia”. (http://www3.petra.ac.id/ library/upload.php?act=get\&id=66, diakses 22 April 2016).

Sooryamoorthy, Radhamany. 2013. Scientific Research in The Natural Sciences in South Africa: A Scientometric Study. Scientific research in natural sciences, 109 (7/8), 1-11.

Vimala, V. \& V. Pulla Reddy. 1996. Authorship Pattern and Collaborative Research in The Field of Zoology. Malaysian Journal of Library \& Information Science, 1 (2), 43-50. 